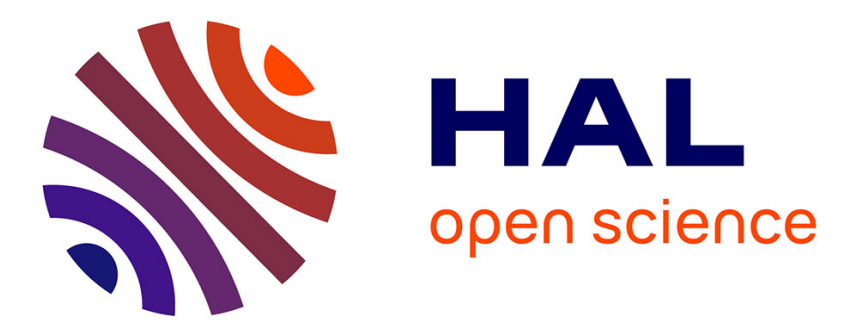

\title{
South Tropical Atlantic anti-phase response to Holocene Bond Events
}

Heitor Evangelista, Marcio Gurgel, Abdelfettah Sifeddine, Nivaor Rodolfo Rigozo, Mohammed Boussafir

\section{- To cite this version:}

Heitor Evangelista, Marcio Gurgel, Abdelfettah Sifeddine, Nivaor Rodolfo Rigozo, Mohammed Boussafir. South Tropical Atlantic anti-phase response to Holocene Bond Events. Palaeogeography, Palaeoclimatology, Palaeoecology, 2014, 415, pp.21-27. 10.1016/j.palaeo.2014.07.019 . insu-01093711

\section{HAL Id: insu-01093711 https://hal-insu.archives-ouvertes.fr/insu-01093711}

Submitted on 15 Dec 2014

HAL is a multi-disciplinary open access archive for the deposit and dissemination of scientific research documents, whether they are published or not. The documents may come from teaching and research institutions in France or abroad, or from public or private research centers.
L'archive ouverte pluridisciplinaire HAL, est destinée au dépôt et à la diffusion de documents scientifiques de niveau recherche, publiés ou non, émanant des établissements d'enseignement et de recherche français ou étrangers, des laboratoires publics ou privés. 


\title{
South Tropical Atlantic anti-phase response to Holocene Bond Events
}

\author{
Heitor Evangelista $^{\mathrm{a}, *}$, Marcio Gurgel ${ }^{\text {e,f }}$, Abdelfettah Sifeddine ${ }^{\mathrm{b}, \mathrm{c}}$, \\ Nivaor Rodolfo Rigozo ${ }^{\mathrm{d}}$, Mohammed Boussafir ${ }^{\mathrm{c}}$
}

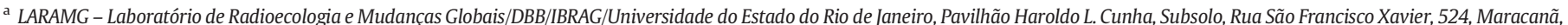
Rio de Janeiro, RJ, 20550-013, Brazil

b Departamento de Geoquimica, Universidade Federal Fluminense, Departamento de Geoquímica/IQ Morro de Valongunho S/n, 5 Andar, Centro, Niterói - RJ, 21020-007, Brazil

c IRD-LOCEAN (UMR 7159 IRD/CNRS/UPMC/MNHN)-Institut Pierre-Simon Laplace, Bondy, France

d Centro Regional Sul de Pesquisas Espaciais/INPE Campus Universitário - UFSM, Caixa Postal no. 5021, Santa Maria, RS, 97105-970, Brazil

e School of Arts, Sciences and Humanities, University of São Paulo, São Paulo, Brazil

${ }^{\mathrm{f}}$ Av. Arlindo Bettio, 1000, CEP03828-000, São Paulo SP, Brazil

\section{A R T I C L E I N F O}

\section{Article history:}

Received 1 August 2013

Received in revised form 14 July 2014

Accepted 19 July 2014

Available online 31 July 2014

\section{Keywords:}

Bond cycles

Atlantic overturning

South Atlantic

Holocene

Alkenone

\begin{abstract}
A B S T R A C T
Records of the climatic impacts of the North Atlantic Bond cycles over the subtropical Southern Hemisphere remain scarce, and their mechanism is a topic of active discussion. We present here an alkenone-based reconstructed sea surface temperature (SST) of a sediment core retrieved from the Brazilian Southwestern Tropical Atlantic (SWTA), Rio de Janeiro, together with a sediment SST record from the Cariaco Basin. The sediment cores span the period 2,100 B.P. - 11,100 B.P. Morlet-wavelet analysis detected marked periodic signals of $\sim 0.8, \sim 1.7$ and $\sim 2.2 \mathrm{kyr}$, very similar and with comparable phases to the hematite-stained-grain time series from the Northern North Atlantic in which the cyclic pattern was recognized as Bond cycles. Our result corroborates the modeled surface ocean anti-phase thermal relation between the North and the South Atlantic. We attribute this behavior to the slowing of the Atlantic Meridional Overturning Circulation. The relative SST warming at Rio de Janeiro and the relative cooling at Cariaco were comparatively more pronounced during the early Holocene (from 11 to 5 kyr B.P.) than in more recent time.
\end{abstract}

(C) 2014 Elsevier B.V. All rights reserved.

\section{Introduction}

The Atlantic Meridional Overturning Circulation (AMOC) is considered to be the primary ocean process in which heat is delivered meridionally between the two hemispheres through the Atlantic Ocean. It carries warm surface waters towards the North Atlantic, where they cool and sink. It is estimated that the AMOC redistributes as much as $\sim 25 \%$ of the global combined atmosphere-ocean heat flux (Cunningham et al., 2010) and that it explains the mild climate conditions observed at the Eastern North Atlantic Ocean sector. It has been speculated that a weakening of the AMOC is likely to occur in the near future due to the effects of anthropogenic greenhouse gas emissions (Cubasch et al., 2001; Bryden et al., 2005; Meehl et al., 2007). This weakening would result in excess melt-water influx from the Arctic and Greenland, which in turn would trigger further climate changes. Nevertheless, the additional meltwater influx is probably not the only cause for AMOC weakening. Results from modeling experiments of Gregory et al. (2005) have indicated that weakening would be caused more by changes in ocean surface heat flux than by changes in surface water flux. In all of the 11 climate models investigated by their work, the

\footnotetext{
* Corresponding author.

E-mail address: evangelista.uerj@gmail.com (H. Evangelista).
}

AMOC does not collapse strongly despite the final concentrations of $\mathrm{CO}_{2}$ reaching 4 times modern values.

During the last glacial, rapid air temperature increases followed by intense cooling are clearly evident in NGRIP Greenland ice core (Andersen et al., 2007), North Atlantic sediment cores (Clement and Peterson, 2008) and Northern Hemisphere palynology (Correa-Metrio et al., 2012). These events were named Dansgaard-Oeschger (D-O) and Heinrich events. They were attributed to influx of meltwater that promoted significant reduction in the strength of AMOC in which effects were globally synchronous. It has been proposed that D-O events were pretty regular with cyclicity around 1470 years (Rahmstorf, 2003). Although much less intense, an apparently analogous climate fluctuation during the Holocene was also recorded from petrologic tracers present in sediment cores from the North Atlantic with a cyclicity of $\sim 1470 \pm$ 500 years and named Bond cycles (Bond et al., 1997). The same cyclicity was found by Bianchi and McCave (1999) using sediment grain-size data that they employed as a proxy of the deep-water flow, an important component of the thermohaline circulation in the Iceland basin. Their grain-size data indicated increased water speeds when the climate of Northern Europe was warmer.

During the last $12 \mathrm{kyr}$, eight occurrences of hematite-stained-grain (HSG) peaks were recognized as ice-rafted debris. Significant correlations obtained between the stacked marine records and cosmogenic 
radionuclides, whose activity concentrations are thought to be modulated by the solar-terrestrial geomagnetic activity, suggested originally that changes in solar activity could be the major forcing agent of these events (Bond et al., 2001). A later study conducted on the cyclicity pattern of the time series using spectral wavelet analysis was able to distinguish between the solar forcing and the oceanic forcing to show that the 1500 -year cycle was basically an ocean-related climate phenomenon (Debret et al., 2007).

The consensus is that the influx of excess meltwater into the Northern North Atlantic, whether forced by anthropogenic causes or due to natural forcings like the Bond events, would have important implications to the regional ocean circulation dynamics. It is proposed that if the AMOC collapses, it would reduce the inter-hemispheric northward heat transport and consequently induce a positive temperature anomaly in the tropical Southern Ocean and induce a bipolar see-saw pattern characterized by a cooling of the northern Atlantic Ocean and warming of the South Atlantic (Crowley, 1992). Nevertheless, no robust experimental evidence from marine records from the Southern Atlantic Ocean exists to show this north-south synchronicity in ocean heat transport. In this work we present reconstructed SST record from Rio de Janeiro that may help to clarify the South Hemisphere response to Holocene Bond cyclicity and that extends our knowledge of the global impact of the Pleistocene $\sim 1500$ yr cyclicity.

\section{Methods}

\subsection{Site description}

The oceanographic system at the coring site has two main components: (1) the prevailing action of the Brazil and the North Brazil Currents ( $\mathrm{BC}$ and $\mathrm{NBC}$ ) that constitute low density tropical waters flowing south/southwest along the Brazilian coast partially over and mostly off the continental shelf; and (2) the South Atlantic Central Water (SACW) that rises at the coast coming from the west, which is most pronounced during austral spring and summer seasons (Coelho-Souza et al., 2012; (Fig. 1). The SACW component is responsible for an important quasi-seasonal upwelling phenomenon that occurs in Cabo Frio at around latitude $23^{\circ} \mathrm{S}$. The upwelling itself occurs when a prevailing northeasterly trade wind dominates in the region (Calado et al., 2008) as a result of a north-south to east-west change in the orientation of the South American shoreline. The intense and constant flow of the $\mathrm{BC}$ and NBC waters, accompanied by a relatively low volume of regional fluvial terrigenous sediment delivery, makes the Southwestern Atlantic coast a region of low sedimentation rates (Mahiques et al., 2005). Along the Southwestern Brazilian coast the BC occupies the top $200 \mathrm{~m}$ of the water column. The SACW is located just below it to the domain of the Antarctic Intermediary Waters. The sediment core was retrieved on the continental shelf, which is the domain of the Plataform Waters (mostly confined near shore) that is fed by meanders of the BC and is seasonally influenced by the oligotrophic waters of the SACW.

\subsection{Sediment core recovery}

The sediment core (ID: CF02-02A) used in the study was collected by the PSV Astro Garoupa Vessel (Astromarítima/PETROBRAS), on 15th August 2002 , at $124 \mathrm{~m}$ water depth $\left(23^{\circ} 16^{\prime} 00^{\prime \prime} \mathrm{S}, 41^{\circ} 48^{\prime} 02^{\prime \prime} \mathrm{W}\right)$. A Kullenberg piston corer was used to recover $228 \mathrm{~cm}$ of sediment from a shelf mud patch made up of grayish hemipelagic mud. The core was sub-sampled continuously at $1 \mathrm{~cm}$ intervals; the sub-samples were oven dried at $<50{ }^{\circ} \mathrm{C}$ and ground in an agate mortar. Core $\mathrm{X}$ ray stratigraphy was performed by the SCOPIX method (Migeon et al., 1999).

\subsection{Sea surface temperature (SST) reconstruction method}

Past SSTs were obtained from the unsaturations ratio of long-chain $\mathrm{C}_{37}$ alkenones: the alkenone unsaturation index, $\mathrm{U}^{\mathrm{K}^{\prime}}{ }_{37}$. These compounds are biosynthesised exclusively by a group of prymnesiophyte algae, principally the coccolithophorid Emiliania huxleyi (Prahl et al., 1988; Marlowe et al., 1990; Volkman et al., 1995). Because of the presence of a natural compound in the samples with the same retention time as the $5-\alpha$-cholestane employed as a quantitative standard and in order to avoid quantification problems, $\mathrm{U}^{\mathrm{K}^{\prime}}{ }_{37}$ was calculated using the peak areas of $C_{37: 2}$ and $C_{37: 3}$ instead of their absolute concentrationstherefore, $\mathrm{U}^{\mathrm{K}^{\prime}}{ }_{37}=\left(\mathrm{C}_{37: 2}\right.$ peak area $) \div\left(\mathrm{C}_{37: 2}\right.$ peak area $+\mathrm{C}_{37: 3}$ peak

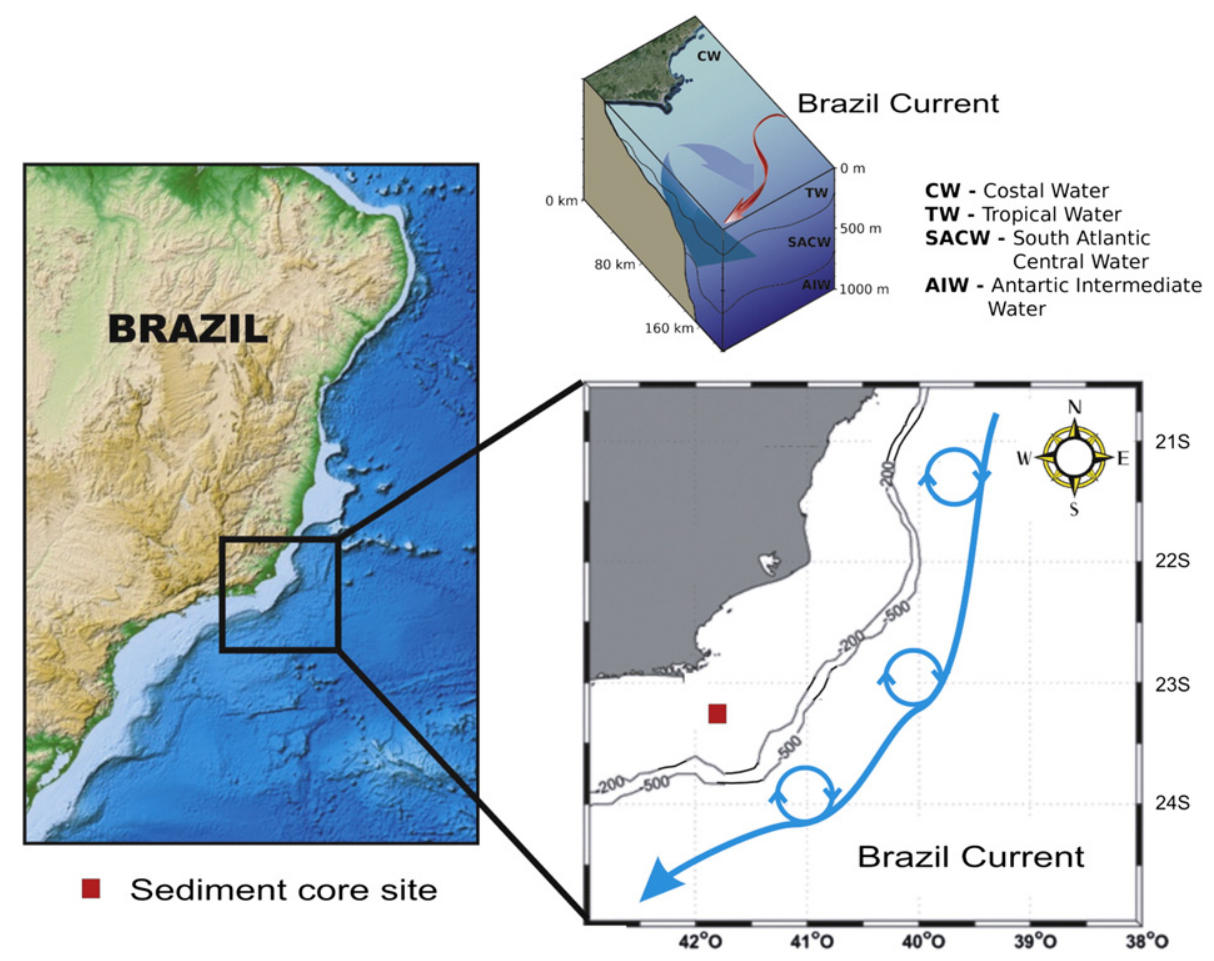

Fig. 1. Main oceanographic features and marine currents at Rio de Janeiro core site. The $500 \mathrm{~m}$ isoline limits the continental shelf. 
area). Alkenone compositions were obtained using an improved method (Peltzer et al., 1984; Ternois et al., 1998). Approximately 2 to $4 \mathrm{~g}$ of dried sample were solvent extracted three times, first with $20 \mathrm{ml}$ of methylene chloride, a second time with $20 \mathrm{ml}$ of methylene chloride and methanol (1:1), and finally a third time with $20 \mathrm{ml}$ of methanol. For each extraction, the samples were ultrasonicated for $15 \mathrm{~min}$ and centrifuged at 2500-3000 rpm for $10 \mathrm{~min}$. All extracts were mixed and concentrated just to dryness using a rotary evaporator and transferred to $4 \mathrm{ml}$ vials. Lipids were partitioned into compound classes (Peltzer et al., 1984). Compound classes were separated into 7 fractions using Pasteur pipettes filled with silica gel (Merck, 0.063-0.100 mm, 5\% deactivated) and eluting with increasing polarity solvents and then stored in $4 \mathrm{ml}$ vials. All fractions were evaporated under a nitrogen stream. Alkenones (fraction 4) were first identified on a ThermoQuest Trace 2000 Series gas chromatograph equipped with a Varian coated fused silica CPSil-5-CB capillary column (60 $\mathrm{m} \times 0.32 \mathrm{~mm}$ i.d., $0.25 \mu \mathrm{m}$ film thickness) coupled to a Finnigan Polaris mass spectrometer. Alkenones were then quantified on a Perkin Elmer Autosytem XL gas chromatograph equipped with the same column and a flame ionization detector. The oven temperature was programmed from 50 to $150{ }^{\circ} \mathrm{C}$ at $30{ }^{\circ} \mathrm{C} \mathrm{min}-1$, followed by $7{ }^{\circ} \mathrm{C} \mathrm{min}^{-1}$ heating until $250{ }^{\circ} \mathrm{C}$ and a final ramp of $1.5^{\circ} \mathrm{C} \mathrm{min}{ }^{-1}$ until $310^{\circ} \mathrm{C}$ and an isothermal hold for $60 \mathrm{~min}$. Helium was used as a carrier gas for both types of analysis. Compounds were identified and quantified using Scalibur and Turbochrom PC-based chromatographic software. Reconstructed Rio de Janeiro SSTs (SSTRJ) are based on alkenones and calculated using the equation $\mathrm{T}\left({ }^{\circ} \mathrm{C}\right)=$ $\left(\mathrm{U}^{\mathrm{K}^{\prime}}{ }_{37}-0.044\right) /(0.033)$ (Müller et al., 1998). Analytical error was $0.9{ }^{\circ} \mathrm{C}$, calculated as three times the standard deviation of random replicate analysis.

\subsection{Sediment core dating and stratigraphy}

Chronology was established using bulk organic matter radiocarbon AMS dating (Angulo et al., 2005). The age control was made using CALIB software. Twelve samples from the core CF02-02A were dated at the L.M.C.14 Laboratory (UMS2572-Laboratoire de Mesure du Carbone 14, CNRS/IRD/CEA/IRSN/MC, Saclay-France). Radiocarbon dating was based on bulk organic matter, and radiocarbon ages were calibrated using CALIB 5.0.1 software (http://calib.qub.ac.uk/calib/) and applying the regional reservoir effect correction $(\Delta R=8 \pm 17)$, according to Angulo et al. (2005). This correction is very similar to that estimated by the Marine Reservoir Correction Database (http://calib.qub. ac.uk/calib/), which was $\Delta \mathrm{R}=-10 \pm 48$.

Digital core stratigraphy was used to detail the internal structure of sedimentary or biological unity by a high resolution X-ray method, the SCOPIX analysis (Migeon et al., 1999; Lofi and Weber, 2001). The core is macroscopically composed of a mix of carbonaceous concretions, shells and other carbonate debris (reworked material) from the base to $195 \mathrm{~cm}$. This composition gradually changes to mud-sands, and from $130 \mathrm{~cm}$ to the core top it becomes a homogeneous dark-gray to olive-gray mud (5GY-4/1 to $5 G-4 / 2$ ). The core log, based on macroscopical observations, SCOPIX gray level values and Rock-Eval results, shows six sedimentary sequences (Fig. 2)

\subsection{Cyclicity patterns from SST reconstruction}

We have conducted two methods of spectral analysis to explore statistically significant cyclicities from reconstructed SSTs (Rio de Janeiro/ Brazil), Cariaco Basin on the Northern Venezuelan Shelf inferred from $\mathrm{Mg} / \mathrm{Ca}$ ratios in surface-dwelling planktonic foraminifera (Lea et al., 2003) and HGS time series (Bond et al., 2001) downloaded from an official data repository/NOAA World Data Center for Paleoclimatology. The methods were the iterative regression analysis (named here ARIST “Análise por Regressão Iterativa de Séries Temporais") (Rigozo et al., 2010), and the Morlet wavelet analysis (Torrence and Compo, 1998; Rigozo et al., 2010). The ARIST method has as a basic concept

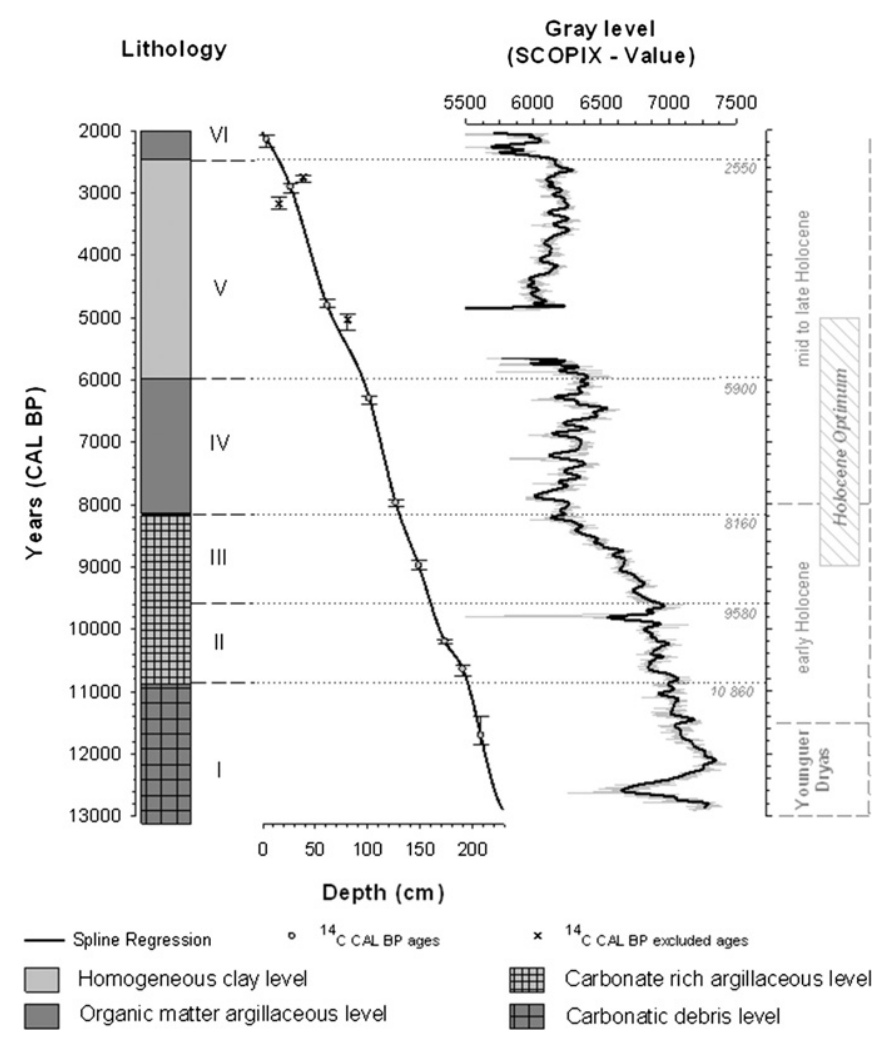

Fig. 2. Core general lithology, core depth vs. calibrated age curve and X-ray imaging scanning ("SCOPI data").

the fitting of sine functions over time series. The simple sine function used in ARIST has 3 parameters to be determined: amplitude, angular frequency and phase, where the starting point of the method is the definition of the so-called conditional function defined as $F=Y-$ $a_{0} \sin \left(a_{1} t+a_{2}\right)$ in which $Y$ is the signal (time series) and $a_{0}, a_{1}, a_{2}$ are the three unknown parameters. For the determination of each parameter we have used 200 iterations for each time series. From the total range of cyclicities detected in each time series by this method, we have taken into consideration, for the interpretation of data, only those cyclicities in which the amplitude/deviation ratio, that is, the cycle amplitude is 2 times higher than the standard deviation. This amplitude corresponds to cyclicities within 95\% significance level. The complex Morlet wavelet analysis was used here to detect important changes in time series and cyclicities. The Morlet Wavelet is a plane wave modulated by a Gaussian function. DWT (discrete wavelet transform) as used here deals with time series defined essentially over a range of integers $(t=0,1, \ldots N-1)$, where $N$ is the number of values in the time series. Therefore if a time series $\mathrm{x}(\mathrm{t})$ is formed by $N$ data points, the DWT $\{\mathrm{x}\}$ will also have $N$ points or $N$ coefficients. The $2^{j-1}$ scales are the wavelet coefficients. The wavelet coefficients are proportional to the difference of averages of the original data and reflect long term variations.

\section{Results}

Reconstructed SSTRJ varied from $24.2{ }^{\circ} \mathrm{C}$ to $28.1{ }^{\circ} \mathrm{C}$ with a mean value of $25.9{ }^{\circ} \mathrm{C}$ and a standard deviation of $0.87{ }^{\circ} \mathrm{C}$, for the period 2100 to 11,100 years B.P. For the same chronology, a mean value of $0.8^{\circ} \mathrm{C}$ higher was estimated for the Cariaco Basin on Fig. 3. During the periods of Bond peaks $(1,2, \ldots, 8)$, SSTs have, on average, decreased from $-0.6{ }^{\circ} \mathrm{C}$ to $-0.3{ }^{\circ} \mathrm{C}$ with respect to the mean from the early Holocene ( $\sim 11 \mathrm{ka}$ to $5 \mathrm{ka}$ ) to late Holocene ( $5 \mathrm{ka}$ to $\sim 2 \mathrm{ka}$ ) in the Cariaco Basin and from $+1.5{ }^{\circ} \mathrm{C}$ to $+0.8{ }^{\circ} \mathrm{C}$ at Rio de Janeiro. For the SST variance, $0.74(n=59)$ for Rio de Janeiro and $0.22(n=45)$ for Cariaco 


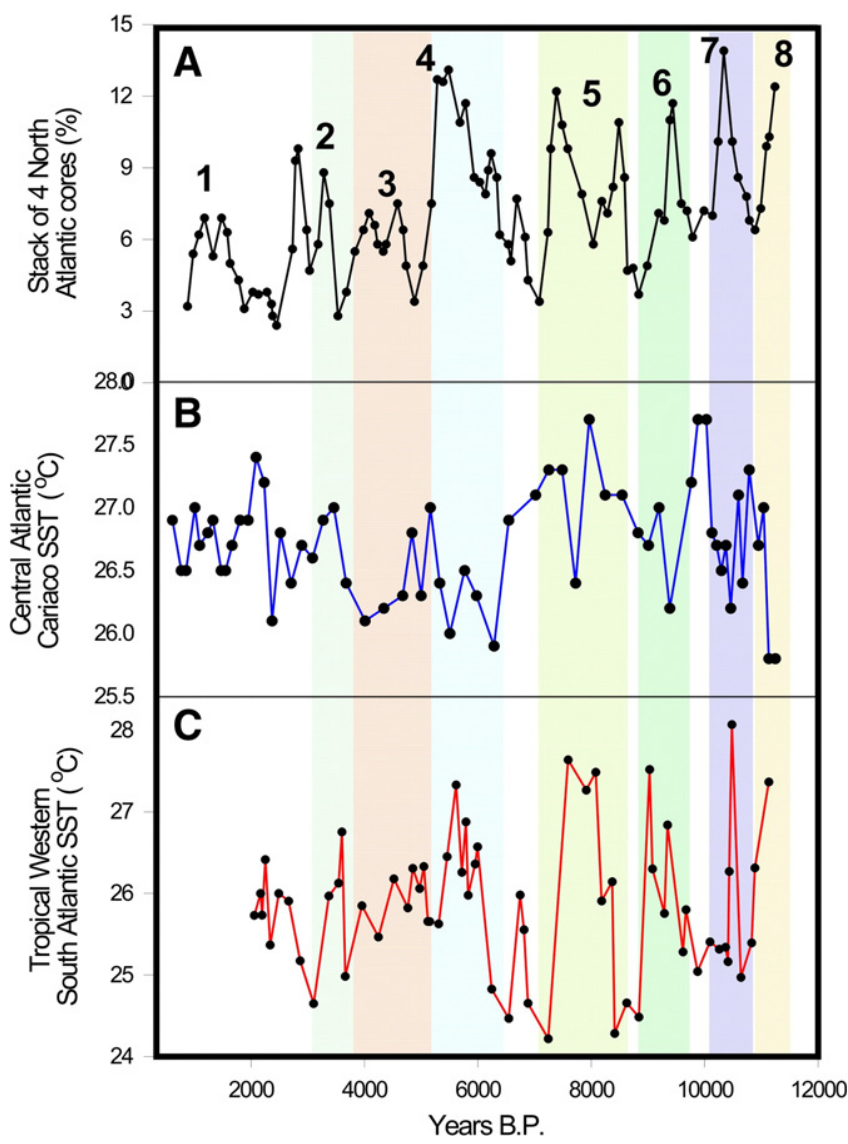

Fig. 3. Sedimentary records at 3 sites along the Atlantic: (A) North Atlantic stacked marine record. Data refers to percent hematite-stained grains (\%HSG); (B) reconstructed Central Atlantic SST at Cariaco Basin based on $\mathrm{Mg} / \mathrm{Ca}$ ratios (Lea et al., 2003); and (C) Southwestern Atlantic SST/Rio de Janeiro derived from alkenones (this paper). Numbers denote the "Holocene Bond Stages" (the millennial-scale cycles recognized in the North Atlantic of nearly 1500-year cyclicity). Vertical boxes highlight, approximately, each Bond event interval.

Basin, the Test-F has yielded evidence of statistical difference at $95 \%$ confidence level $\left(\mathrm{F}_{\text {critic }}=1.61\right.$ and $\left.\mathrm{F}=3.28\right)$ between the sites.

Results of Morlet wavelet analysis reinforce the apparent NorthernCentral-Southern Atlantic synchronicity (Fig. 4). The spectral analysis revealed two statistically significant oscillatory bands ( $\sim 0.8 \mathrm{kyr}$ and one extending from $\sim 1.7$ to $2.5 \mathrm{kyr}$ ) dominating the 3 investigated sites, that is consistent to previously reported spectral analysis (Debret et al., 2007).

From the ARIST spectral method we were able to retrieve main oscillatory signals from the 3 time series, identified phases and correlations. The technique allowed a deconvolution of the periodic bands detected by the wavelet spectral analysis so that the $1.7 \mathrm{kyr}$ and $2.2 \mathrm{kyr}$ signals were recognized apart. Fig. 5 depicts the total cyclicities detected by the ARIST method with intervals of statistical significance with respect to 1 and 2 standard deviation.

Fig. 6 shows superimposed $0.8 \mathrm{kyr}, 1.7 \mathrm{kyr}$ and $2.2 \mathrm{kyr}$ signals of Bond and SSTRJ and Bond and Cariaco Basin, and r-Pearson correlation coefficients among oscillatory signals. An interesting finding here is the high correlation values varying from 0.89 to 0.99 between the retrieved cycles. This correlation means a great coherency between the signals when the time lag is adequately adjusted.

\section{Discussion}

A comparison between the time series of the reconstructed SSTs and the Holocene Bond Stages (HBS) $(1,2, \ldots, 8)$ verifies that almost all HBS were well recognized. The ARIST method indicated a bi-polar synchronicity between the increasing HSG delivery into the North Atlantic Ocean floor and the increasing SST in the tropical Southwestern Atlantic. Extending the comparison to the Cariaco Basin, SST peaks are predominantly in opposite phase with respect to Bond events, indicating that cooler periods in the Cariaco Basin coincided with cooling in the Northern North Atlantic.

Considering the different reconstruction methods employed in each sediment core, the analytical error for alkenone determination, as described here, and the amplitude of the variance, the mean SSTs derived from Cariaco and Rio de Janeiro cannot be assumed as statistically different, a result that can be also achieved with the use of a two-tailed Student's t-test at 95\% confidence level. Nevertheless, during the Bond events, Rio de Janeiro SSTs may reach levels comparable to the Cariaco average despite the difference of the mean direct solar radiation between the two sites.

The mechanism responsible for the anti-phase relation between the Northern and Southern Hemispheres of the Atlantic is well documented. The AMOC transports heat and salt towards the Northern Hemisphere, but when increased melt-water is delivered to Northern subpolar regions and vicinities, a slowing of the AMOC may result in the accumulation of heat and salt in the Southern Hemisphere, a process called the bipolar seesaw (Crowley, 1992; Manabe and Stouffer, 1995; Broecker, 1998). The reconstructed SSTRJ data seem to support this mechanism. The described mechanism is also consistent with coupled ocean-atmosphere general circulation models (e.g.: Dahl et al., 2005). In their model they added $0.1 \mathrm{~Sv}$ (1Sv: 1 Sverdrup $=10^{6} \mathrm{~m}^{3} \mathrm{~s}^{-1}$ ) of freshwater into the North Atlantic for 100 years. Under such condition the AMOC is estimated to be reduced by roughly $40 \%$, cooling the North Atlantic region up to $8^{\circ}$, and both air temperature and SST are expected to increase from the North towards the Equator. One consequence of this scenario is the southwards shift of the ITCZ, along with changes in the trade winds and an asymmetric response of the Hadley circulation (Broccoli et al., 2006). In the Cariaco Basin, the observed response to these Holocene oscillations can be interpreted as a small scale response to the climate oscillations that took part during last glacial termination, as revealed by the Greenland Ice Sheet Project 2, when a quasi synchronicity response was recorded (Lea et al., 2003).

With regard to the alkenone-derived Holocene SST trends for the Atlantic, data from Rio de Janeiro presented a near neutral pattern. In particular, the last $5 \mathrm{kyr}$ showed a decrease of $\sim-1{ }^{\circ} \mathrm{C}$ to the present. In this context the Leduc et al. (2010) study found robust cooling trends towards the present for the Northern Atlantic as far south as $\sim 30^{\circ} \mathrm{N}$. Between $15^{\circ} \mathrm{N}$ and $15^{\circ} \mathrm{S}$ a predominant SST reversal (warming trend) was observed. However, SST reconstructions south of $15^{\circ} \mathrm{S}$ are lacking in the Atlantic. SST reconstructions for the Pacific and Indian Ocean present high prevalence of cooling southwards of this latitudinal band (Leduc et al., 2010). It is clear from Fig. 1 that a change in variability pattern at the 3 time series occurs before and after $\sim 5 \mathrm{yr}$-B.P. This midHolocene transition accompanies a worldwide climate variability well documented for the Polar Regions in Antarctica and Greenland. In the tropicas and subtropics the climate signals of this transition are more ambiguous, varying from cooling to aridity regimes according to palynology records, speleothems, or lake sediment data (Steig et al., 1997).

The cross-wavelet analysis performed between the tropical sites and HSG time series indicated that the $\sim 1.7-2.5 \mathrm{kyr}$ band was persistent during a significant time interval of the Holocene ( $3.5 \mathrm{kyr}$ and $9 \mathrm{kyr})$, but it became weaker towards the modern epoch, while the synchronicity was more prominent between $\sim 4$ and $9 \mathrm{kyr}$. The response to the $\sim 0.8$ kyr oscillatory response was dominant through the late Holocene. Combining the Holocene and the last glacial period, HSG data from North Atlantic sediment cores exhibit a cyclicity centered at $1470 \pm 532$ years. Therefore, the Bond event cyclicity essentially spanned $\sim 938$ years to 2002 years. Based on the wavelet Morlet analysis the main cyclic pattern obtained for Rio de Janeiro and Cariaco corresponds to a broad interval from $\sim 1700$ to 2500 years and therefore lies mostly within the cyclicity interval detected by Bond et al. 


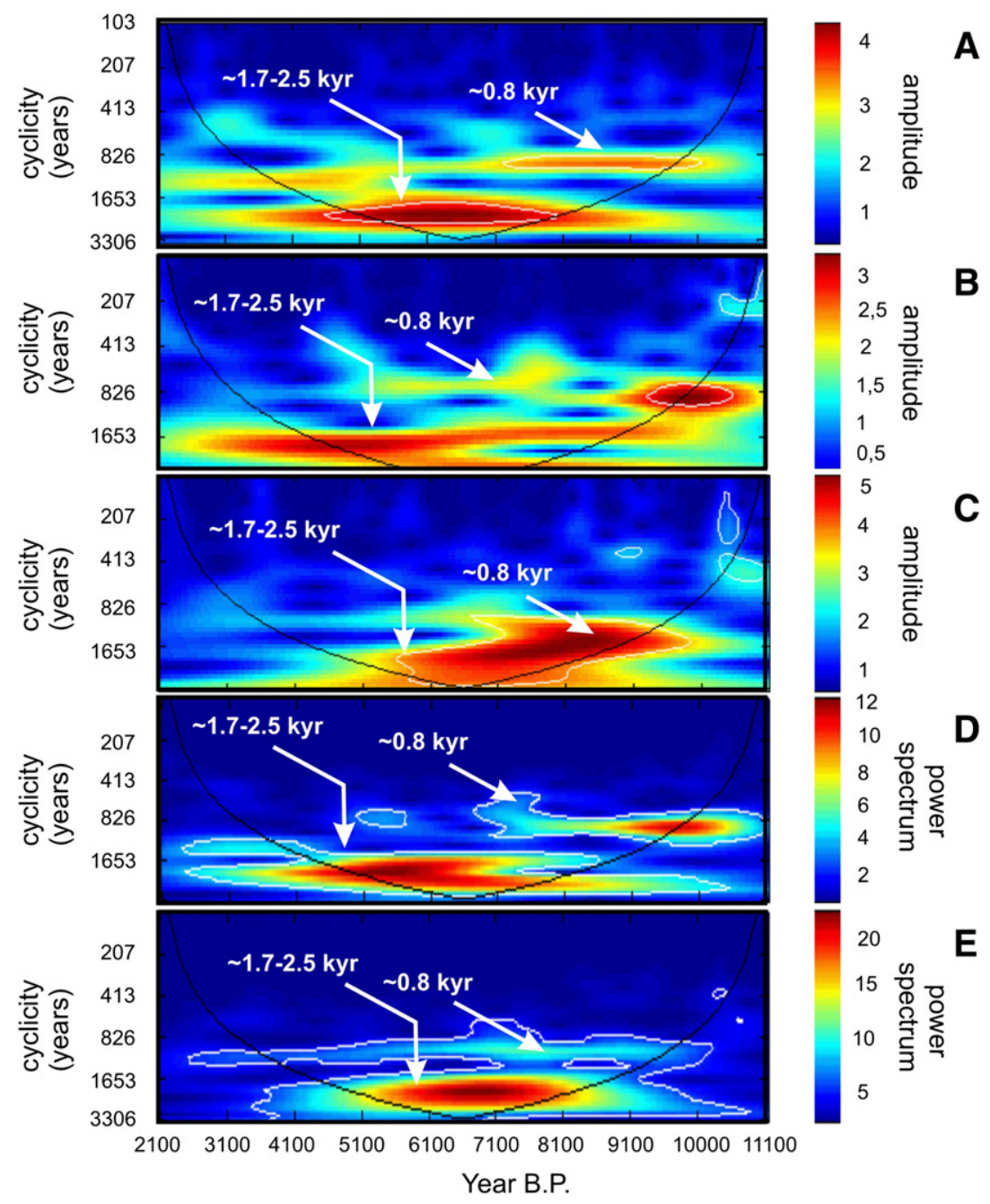

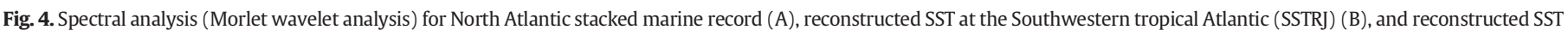

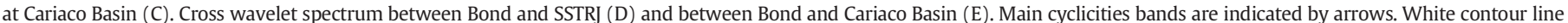
defines the cyclicities within $95 \%$ confidence level and black continuous line defines the cone of significance of the analysis.

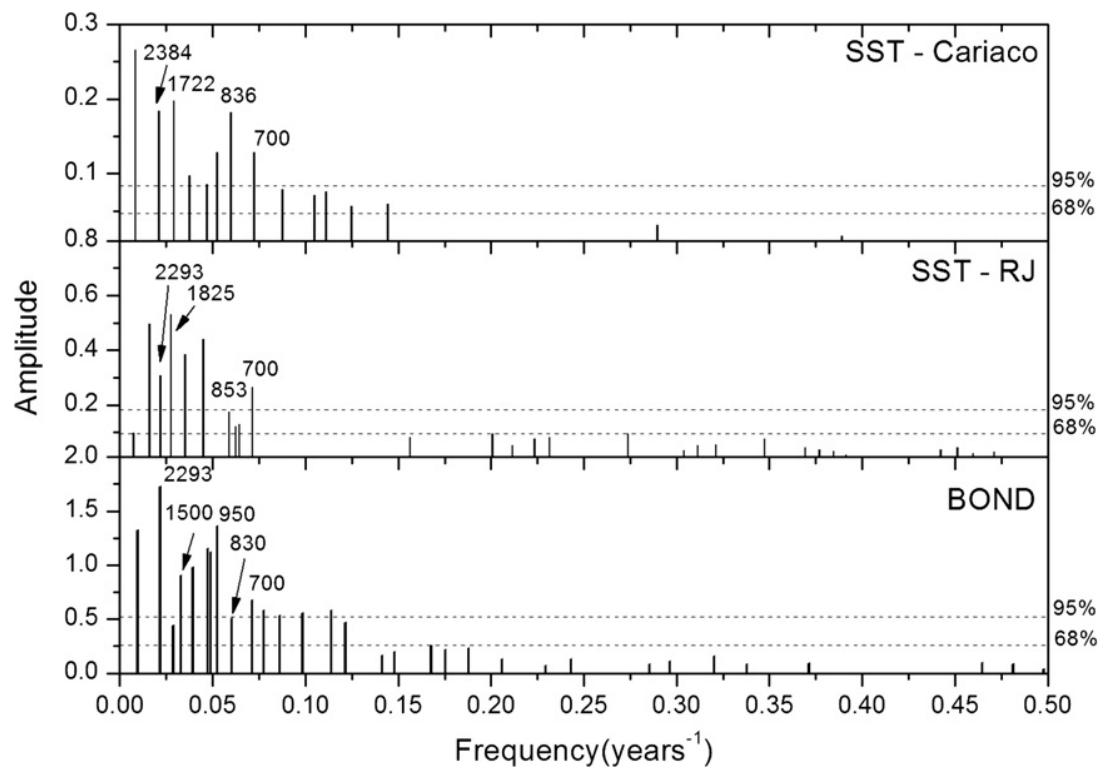

Fig. 5. Cyclicities (yr) and intervals of statistical significance from ARIST method for Cariaco and Rio de Janeiro SST reconstructions and hematite-stained grains (\%HSG). 

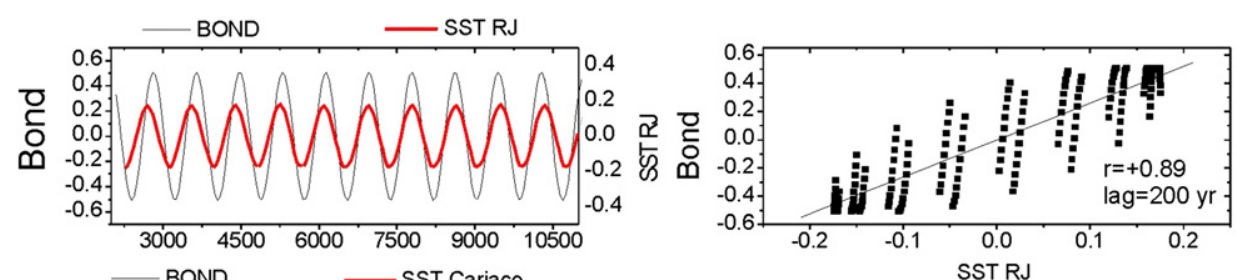

A
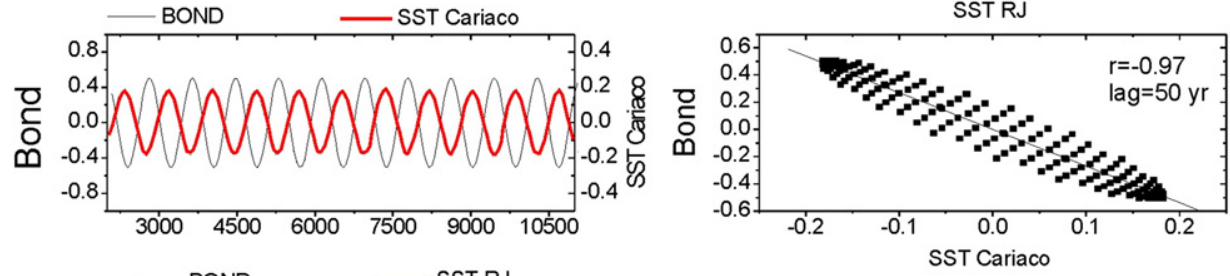

B
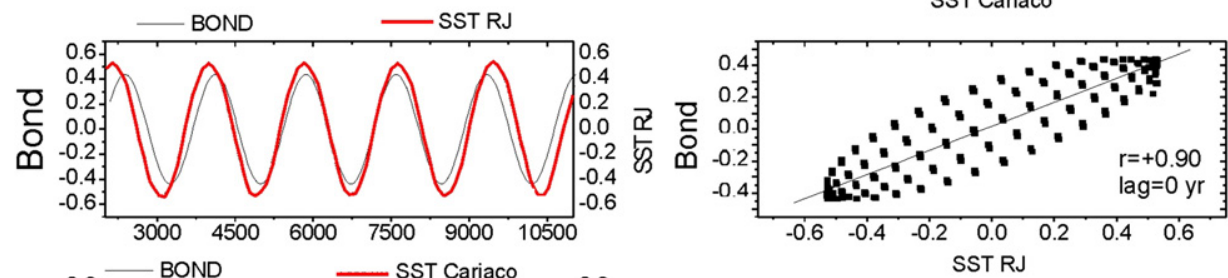

C
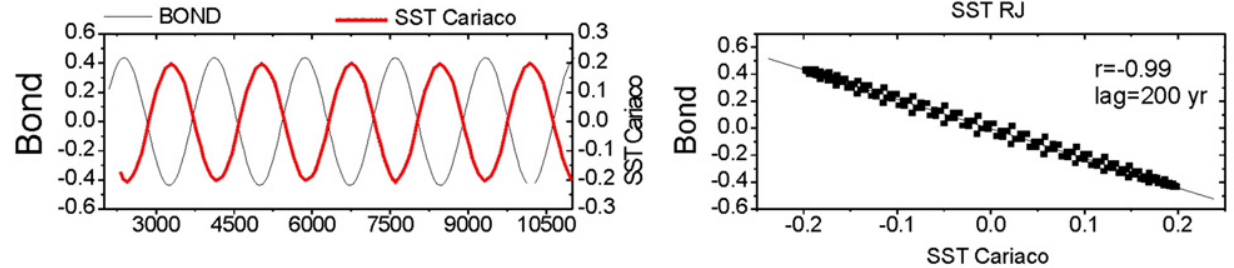

D


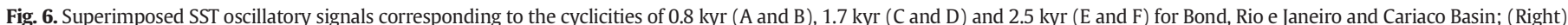

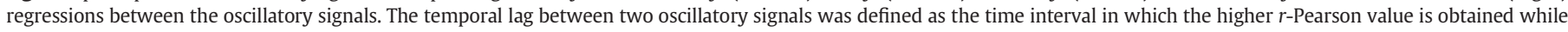
performing a lag correlation.

From our observations, we conclude that the transition from a neutral response to Bond events to warming of surface water masses that is caused by the retention of heat in the Tropical-to-Polar Atlantic waters as a consequence of the AMOC slowing may take place well below the Equator and likely in tropical-subtropical latitudes. There is a clear need for better definition of this geographical boundary, which may be under the influence of North Atlantic Bond events, using new sediment core analyses. Time lags between oscillatory signals were found to vary between 50 and $200 \mathrm{yr}$. This time interval is comparable to the estimates of inter-hemispheric transport of water masses. Nevertheless, this interpretation should be considered with caution considering the resolution of the data of this study.

\section{Conclusions}

This work presents a new alkenone-based SST record covering the part of the Holocene from $2.1 \mathrm{kyr}$ B.P. to $11.1 \mathrm{kyr}$ B.P. from a shelf site in the Southwestern South Atlantic and compares it to the SST record from the Carioca Basin. Spectral analyses performed with Morletwavelet and ARIST methods reproduced marked oscillatory signals of $\sim 0.8 \mathrm{kyr}, \sim 1.7 \mathrm{kyr}$ and $\sim 2.2 \mathrm{kyr}$ for reconstructed SSTs off Rio de Janeiro and from Cariaco and the hematite-stained-grain time series in the Northern North Atlantic that are recognized as Bond cycles within statistic significance. Time lags between events (Bond peaks) in the North Atlantic and the South Atlantic at the tropics were estimated to occur at a maximum interval of $200 \mathrm{yr}$. We attribute the anti-phase thermal relation to the slowing of the Atlantic Meridional Overturning Circulation as described previously by several authors. The relative SST warming at Rio de Janeiro and the relative cooling at Cariaco seemed to be more pronounced during the early Holocene (from $11 \mathrm{kyr}$ to 5 kyr B.P.). Although our analyses for the Southwestern Atlantic reproduce the Northern Hemisphere main cyclicity patterns they are one of the initial alkenone-based SST reconstructions inside the vast Southwestern Atlantic sector and have the additional caveat that they have low-to-moderate resolution. Our results nonetheless provide strong encouragement towards improving SST reconstructions on the Brazilian 
continental shelf to investigate the Southern Tropical Atlantic response to Bond events.

\section{Acknowledgments}

We acknowledge support from LMI PALEOTRACES (IRD/UFF/Uantof/ UPCH/UPMC), Id. 300448/00; CLIMPAST Project (CNPq/IRD 490735/ 2006) and PRIMO Project (CNPq/IRD 590172/2011-5). We also thank two reviewers of Palaeogeography, Palaeoclimatology, Palaeoecology for their valuable suggestions that considerably improved this contribution.

\section{References}

Andersen, K.K., Bigler, M., Clausen, H.B., Dahl-Jensen, D., Johnsen, S.J., Rasmussen, S.O., Seierstad, I., Steffensen, J.P., Svensson, A., Vinther, B.M., Davies, S.M., Muscheler, R., Parrenin, F., Röthlisberger, R., 2007. A 60000 year Greenland stratigraphic ice core chronology. Clim. Past Discuss. 3, 1235-1260.

Angulo, R.J.,Souza, M.C., Reimer, P.J., Sasaoka, S.K., 2005. Reservoir effect of the southern and southeastern Brazilian coast. Radiocarbon 47 (1), 67-73.

Bianchi, G.G., McCAVE, I.N., 1999. Holocene periodicity in North Atlantic climate and deep ocean flow south of Iceland. Nature 397, 515-517.

Bond, G., Showers, W., Cheseby, M., Lotti, R., Almasi, P., deMenocal, P., Priore, P., Cullen, H., Hajdas, I., Bonani, G., 1997. A pervasive millennial-scale cycle in North Atlantic Holocene and glacial climates. Science 278, 1257-1266.

Bond, G., Kromer, B., Beer, J., Muscheler, R., Evans, M.N.,Showers, W.,,Hoffmann, S., LottiBond, R., Hajdas, I., Bonani, G., 2001. Persistent solar influence on north Atlantic climate during the Holocene. Science 294 (5549), 2130-2136.

Broccoli, A.J., Dahl, K.A.,Stouffer, R.J., 2006. Response of the ITCZ to Northern Hemisphere cooling. Geophys. Res. Lett. 33 (L01702).

Broecker, W.S., 1998. Paleocean circulation during the last deglaciation: a bipolar seesaw? Paleoceanography 13, 119-121.

Bryden, H.L., Longworth, H.R., Cunningham, S.A., 2005. Slowing of the Atlantic Meridional Overturning Circulation at $26.5^{\circ} \mathrm{N}$. Nature 438 (10.1038), 655-657.

Calado, L.,Gangopadhyay, A.A. da Silveira, I.C.A., 2008. Feature-oriented regional modeling and simulations (FORMS) for the western South Atlantic: Southeastern Brazil region. Ocean Model. 25, 48-64.

Clement, A.C.,Peterson, L.C., 2008. Mechanisms of abrupt climate change of the last glacial period. Rev. Geophys, 46, 1-39.

Coelho-Souza, S.A., López, M.S., Guimarães, J.R.D., Coutinho, R., Candella, R.N., 2012. Biophysical interactions in the Cabo Frio upwelling system, Southeastern Brazil. Braz. J. Oceanogr. 60 (3), 353-365.

Correa-Metrio, A., Bush, M.B., Cabrera, K.R., Sully, S., Brenner, M., Hodell, D.A., Escobar, J., Guilderson, T., 2012. Rapid climate change and no-analog vegetation in lowland Central America during the last 86,000 years. Quat. Sci. Rev. 38, 63-75.

Crowley, T.J., 1992. North Atlantic Deep Water cools the Southern Hemisphere. Paleoceanography 7, 489-497.

Cubasch, U., Meehl, G.A., Boer, G.R.,Stouffer, R.J.,Dix, M., Noda, A.,Senior, C.A., Raper, S., Yap K.S.,Abe-Ouchi, A.,Brinkop, S.,Claussen, M.,Collins, M.,Evans, J., Fischer-Bruns, L.,Flato, G., Fyfe, J.C., Ganopolski, A., Gregory, J.M., Hu, Z.-Z., Joos, F., Knutson, T., Knutti, R. Landsea, C., Mearns, L., Milly, C., Mitchell, J.F.B., Nozawa, T., Paeth, H., Sausen, R.J., Smith, S., Stocker, T., Timmerman, A., Ulbrich, U., Weaver, A., Wegner, J., Whetton, P. Wigley, T., Winton, M.,Zwiers, F., 2001. Projections of future climate change. In: Houghton, J.T., Ding, Y., Griggs, D.J., Noguer, M., van der Linden, P.J., Dai, X., Maskell, K., Johnson, C.A. (Eds.), Climate Change 2001: The Scientific Basis. Cambridge University Press, Cambridge, pp. 555-582.

Cunningham, S., Baringer, M.,Johns, B., Toole, J.,Østerhus, S., Fischer, J.,Piola, A., McDonagh, E., Lozier, S.,Send, U., Kanzow, T.,Marotzke, J., Rhein, M., Garzoli, S., Rintoul, S.,Sloyan, B., Speich, S., Talley, L., Baehr, J., Meinen, C., Treguier, A.M., Lherminier, P., 2010. The present and future system for measuring the Atlantic meridional overturning circulation and heat transport. In: Hall, J., Harrison, D.E., Stammer, D. (Eds.),
Proceedings of OceanObs'09: Sustained Ocean Observations and Information for Society, pp. 229-244.

Dahl, K.A.,Broccoli, A.J.,Stouffer, R.J., 2005. Assessing the role of North Atlantic freshwater forcing in millennial scale climate variability: a tropical Atlantic perspective. Clim. Dyn. 24, 325-346.

Debret, M., Bout-Roumazeilles, V.,Grousset, F.,Desmet, M., McManus, J.F., Massei, N.,Sebag, D., Petit, J.R., Copard, Y., Trentesaux, A., 2007. The origin of the 1500-year climate cycles in Holocene North-Atlantic records. Clim. Past 3, 569-575.

Gregory, J.M., Dixon, K.W., Stouffer, R.J., Weaver, A.J., Driesschaert, E., Eby, M., Fichefet, T., Hasumi, H., Hu, A., Jungclaus, J.H., Kamenkovich, I.V., Levermann, V., Montoya, M., Murakami, S., Nawrath, S., Oka, A., Sokolov, A.P., R. B., 2005. ThorpeA model intercomparison of changes in the Atlantic thermohaline circulation in response to increasing atmospheric $\mathrm{CO}_{2}$ concentration. Geophys. Res. Lett. 32, L12703.

Lea, D.W., Pak, D.K., Peterson, L.C., Hughen, K.A., 2003. Synchroneity of tropical and highlatitude Atlantic temperatures over the last glacial termination. Science 301 (5638), 1361-1364.

Leduc, G., Schneider, R., Kim, J.-H., Lohmann, G., 2010. Holocene and Eemian sea surface temperature trends as revealed by alkenone and $\mathrm{Mg} / \mathrm{Ca}$ paleothermometry. Quat. Sci. Rev. 29, 989-1004.

Lofi, J., Weber, O., 2001. SCOPIX-digital processing of X-ray images for the enhancement of sedimentary structures in core slabs. Geo-Mar. Lett. 20, 182-186.

Mahiques, M.M.,Bícego, M.C.Silveira, I.C.A.,Sousa, S.H.M.,Lourenço, R.A.,Fukumoto, M.M. 2005. Modern sedimentation in the Cabo Frio upwelling system, Southeastern Brazilian shelf. Ann. Braz. Acad. Sci. 77 (3), 535-548.

Manabe, S.,Stouffer, R.J., 1995. Simulation of abrupt climate change induced by freshwater input to the North Atlantic Ocean. Nature 378, 165-167.

Marlowe, I.T., Brassell, S.C., Eglinton, G., Green, J.C., 1990. Long-chain alkenones and alkyl alkenoates and the fossil coccolith record of marine sediments. Chem. Geol. 88, 349-375.

Meehl, G.A., Stocker, T.F., Collins, W.D., Friedlingstein, P., Gaye, A.T., Gregory, J.M., Kitoh, A., Knutti, R., Murphy, J.M., Noda, A., Raper, S.C.B., Watterson, I.G., Weaver, A.J.,Zhao, Z.-C., 2007. Global climate projections. In: Solomon, S., Qin, D., Manning, M., Chen, Z., Marquis, M., Averyt, K.B., Tignor, M., Miller, H.L. (Eds.), Climate Change 2007: The Physical Basis. Contribution of Working Group I to the Fourth Assessment Report of the Intergovernmental Panel on Climate Change. Cambridge University Press, Cambridge, UK, and New York, pp. 747-845.

Migeon, S., Weber, O., Faugères, J.C., Saint-Paul, J., 1999. SCOPIX: a new X-ray imaging system for core analysis. Geo-Mar. Lett. 18 (3), 251-255.

Müller, P.J., Kirst, G., Ruhland, G., von Storch, I., Rosell-Mellé, A., 1998. Calibration of the alkenone paleotemperature index UK37' based on core-tops from the eastern South Atlantic and the global ocean $\left(60^{\circ} \mathrm{N}-60^{\circ} \mathrm{S}\right)$. Geochim. Cosmochim. Acta 62 (10), 1757-1772.

Peltzer, E.T.,Alford, J.B., Gagosian, R.B., 1984. Methodology for sampling and analysis of lipids in aerosols from the remote marine atmosphere. Technical Report. Woods Hole Oceanographic Institution, Woods Hole, MA, p. 104.

Prahl, F.G., Muehlhausen, L.A., Zahnle, D.L., 1988. Further evaluation of long-change alkenones as indicators of paleoceanographic conditions. Geochim. Cosmochim. Acta 52, 2303-2310.

Rahmstorf, S., 2003. Timing of abrupt climate change: a precise clock. Geophys. Res. Lett. 30 (10), 1510.

Rigozo, N.R., Nordemann, D.J.R.,Echer, E., Echer, M.P.S.,Silva, H.E., 2010. Prediction of solar minimum and maximum epochs on the basis of spectral characteristics for the next millennium. Planet. Space Sci. 58, 1971-1976.

Steig, E.J., Hart, C.P., White, J.W.C., Cunningham, W.L., Davis, M.D., Saltzman, E.S., 1997. Changes in climate, ocean and ice-sheet conditions in the Ross embayment, Antarctica, at 6 ka. Ann. Glaciol. 27, 305-310.

Ternois, Y.,Sicre, M.A., Boireau, A.,Beaufort, L., Miquel, J.C.,Jeandel, C., 1998. Hydrocarbons, sterols and alkenones in sinking particles in the Indian Ocean sector of the Southern Ocean. Org. Geochem. 28 (7-8), 489-501.

Torrence, C., Compo, G.P., 1998. A practical guide to wavelet analysis. Bull. Am. Meteorol. Soc. 79, 61-78.

Volkman, J.K., Barrett, S.M., Blackburn, S.I., Sikes, E.L., 1995. Alkenones in Gephyrocapsa oceanica: implications for studies of paleoclimate. Geochim. Cosmochim. Acta 59 (3), 513-520. 